九州大学学術情報リポジトリ

Kyushu University Institutional Repository

\title{
A Study on Heat Transfer of Paulownia coreana and High-Density Fiberboard via Comparative Analysis
}

\section{Kang, Seog-Goo}

Department of Bio-Based Materials, College of Agriculture \& Life Sciences, Chungnam National University

\section{Lee, Sol-Ae}

Department of Bio-Based Materials, College of Agriculture \& Life Sciences, Chungnam National University

Son, Dong-Won

Dept. of Forest Products Korea Forest Research Institute

Kang, Chun-Won

Department of Housing Environmental Design, and Researc hInstitute of Human Ecology, College of Human Ecology, Chonbuk National University

他

https://doi.org/10.5109/1526303

出版情報: 九州大学大学院農学研究院紀要. 60 (1)，pp.191-195，2015-02-27. Faculty of Agriculture, Kyushu University

バージョン :

権利関係 : 


\title{
A Study on Heat Transfer of Paulownia coreana and High-Density Fiberboard via Comparative Analysis
}

\author{
Seog-Goo KANG ${ }^{1}$, Sol-Ae LEE ${ }^{1}$, Dong-Won SON ${ }^{2}$, \\ Chun-Won KANG ${ }^{3 *}$ and Junji MATSUMURA
}

\author{
Laboratory of Wood Science, Department of Forest and Forest Product Science, \\ Faculty of Agriculture, Kyushu University, Fukuoka 812-8581, Japan \\ (Received October 29, 2014 and accepted November 14, 2014)
}

\begin{abstract}
The heat transfer and thermal efficiency of Paulownia coreana (low-density wood) and high-density fiber board were measured via a comparative analysis of heat transfer, and the suitability of the wood as a finishing material was evaluated. A comparative analysis of heat transfer is calculated by verifying the heat transfer and change in temperature of the water bottle both inside and outside of the sample box. The total transferred heat is then divided by conduction, convection, and radiation. The results show $18.05 \mathrm{~W}$ of heat was transferred to water bottle in the low-density Paulownia coreana UYEKI, and $12.5 \mathrm{~W}$ in the high-density fiberboard. The total heat from the heating source was $30 \mathrm{~W}$. This indicates that a heat loss of low density wood was smaller than that of high density fiberboard. A difference was found in the amount of heat transferred, with a majority due to radiation: $0.02 \mathrm{~W}$ of conduction, $1.5 \mathrm{~W}$ of convection, and $3.98 \mathrm{~W}$ of radiation. These results indicate that the low density wood is appropriate for use as a thermal insulation building material.
\end{abstract}

Key words: energy efficiency, heat transfer, Paulownia coreana, high density fiber board, radiation, insulation

\section{INTRODUCTION}

Wood is a commonly-used construction material because of its unique appearance, high specific strength, and thermal insulation properties. In addition, wood is durable, has a general visual appeal, and a low maintenance cost. When used as a material for the interiors of buildings, its superior insulation properties lead to savings in the cost of cooling and heating. The thermal efficiency and therefore cost savings vary with wood type, which makes this of critical importance (Richardson, 1976).

There are three ways that heat can move; conduction, convection, and radiation. Thermal conduction occurs between two connected objects, and represents a move in energy from high temperature to low temperature molecules without any material shift. Thermal convection is where a heated fluid ascends while the surrounding fluid flows in to fill the empty space. Thermal radiation is the emission of electromagnetic waves from all matter with a temperature above absolute zero (Lee and Bender, 2009). This radiation represents the conversion of thermal energy to electromagnetic energy, and among the three heat transfer methods, plays the most prominent role in typical industrial application studies. This is important in the case of household applications,

\footnotetext{
1 Department of Bio-Based Materials, College of Agriculture \& Life Sciences, Chungnam National University, Daejeon 305764 , South Korea

2 Dept. of Forest Products Korea Forest Research Institute, Seoul 130-712, Korea

Department of Housing Environmental Design, and Research Institute of Human Ecology, College of Human Ecology, Chonbuk National University, Jeonju 561-756, Korea

* Corresponding author (E-mail:kcwon@jbnu.ac.kr)
}

where the majority of heat loss occurs in the form of radiation through the walls and ceiling. It is, therefore, critical to evaluate the thermal environment and observe the movement of heat to determine energy saving opportunities. In the construction industry, the heat conductivity of a material is the basic element for energy saving (Kim et al., 2006).

Wood is known to be a stable material with high solidity, insulation, and low heat conductivity properties. The specific heat of wood is approximately 0.29 , which is similar to air. The heat conductivity of wood is approximately 1.05 2.98, which is lower than that of other building materials.

In this study, to compare the heat transfer variance between wood and wood based materials, we investigated differences in heat movement and the insulation abilities of these materials. We made two specimen boxes, one of low specific gravity wood and one of high specific gravity wood based board, Paulownia coreana and High

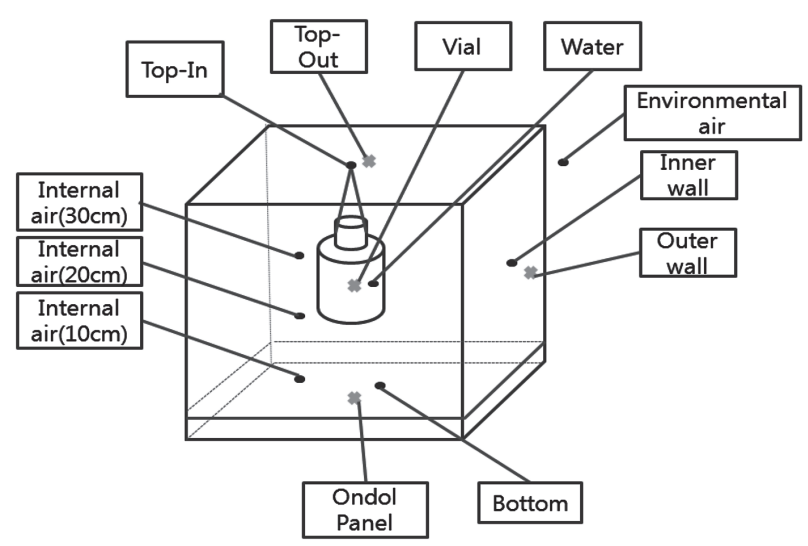

Fig. 1. Installation of the thermocouple. 
Table 1. Specimen properties

\begin{tabular}{lccccc}
\hline & $\begin{array}{c}\text { Thickness } \\
(\mathrm{mm})\end{array}$ & $\begin{array}{c}\text { Specific } \\
\text { Gravity }\end{array}$ & $\begin{array}{c}\text { Moisture } \\
\text { Content }(\%)\end{array}$ & $\begin{array}{c}\text { Thermal } \\
\text { conductivity } \\
\left(\mathrm{W} / \mathrm{m} \cdot{ }^{\circ} \mathrm{C}\right)\end{array}$ & Emissivity \\
\hline Paulownia coreana & 12 & 0.27 & 12.5 & 0.08 & 0.90 \\
High-density fiberboard & 8 & 0.89 & 6.6 & 0.10 & 0.85 \\
\hline
\end{tabular}

Density Fiberboard (HDF), respectively. We then measured the temperatures at several locations both inside and outside the box, as shown in Fig. 1. Ondol flooring was used for the bottom of the box, and to apply a floor heating radiation system similar those used commonly in Korean architecture.

\section{MATERIALS AND METHODS}

\section{Testing materials}

Ondol flooring $7 \mathrm{~mm}$ in thickness was used for the bottom of the sample box for floor heating. Paulownia coreana and high-density fiber (HDF) laminated floor boards were used for the walls and the top of the sample, respectively. The applicable properties of these materials are listed in Table 1.

\section{Test methods}

Wood and HDF sample boxes are regular hexahedrons, and the dimension of each section is $400 \times 400 \mathrm{~mm}$. Ondol flooring which is heated and temperature controlled electrically was used for the bottom of sample boxes. Paulownia coreana and HDF were used for the walls and top of the sample box, respectively, and glued with Silicon. All wall sections have a $5 \sim 7 \mathrm{~mm}$ diameter hole in the center to allow for the placement of a thermocouple. The top of the sample box was assembled using the same materials as the walls, and two holes of identical diameter were placed in the center. A vial was set

Table 2. Properties of sample boxes

\begin{tabular}{ccccc}
\hline $\begin{array}{c}\text { Diameter of } \\
\text { entrance } \\
(\mathrm{mm})\end{array}$ & $\begin{array}{c}\text { Diameter of } \\
\text { bottle } \\
(\mathrm{mm})\end{array}$ & $\begin{array}{c}\text { Height } \\
(\mathrm{mm})\end{array}$ & $\begin{array}{c}\text { Weight } \\
(\mathrm{g})\end{array}$ & $\begin{array}{c}\text { hermal } \\
\text { conductivity } \\
\left(\mathrm{W} / \mathrm{m} \cdot{ }^{\circ} \mathrm{C}\right)\end{array}$ \\
\hline 20 & 65 & 125 & 1492 & 1.02 \\
\hline
\end{tabular}

$100 \mathrm{~mm}$ below the top of the sample box containing $200 \mathrm{~g}$ of water covered with parafilm. The applicable properties of the sample box are listed in Table 2.

The sample boxes were glued with silicon to a heating panel with dimensions of $400 \times 400 \mathrm{~mm}$. The thermocouple was set on the internal and outer walls, in the vial of water, and in various suspended locations as shown in Figure. 1.

Sample boxes were put in a room with constant temperature and humidity and connected to controllers. The temperature of the controller was set to $45^{\circ} \mathrm{C}$ and maintained there for 3 hours. After heating, the controllers were turned off until the temperature of the sample box decreased to the initial temperature. Temperature was measured at 10-minute intervals, and the entire temperature cycle was performed two times. All experiments were performed following KS L 9016 and KS F 3103.

\section{RESULTS AND DISCUSSION}

\section{Comparison of heat transfer}

The heat transfer analysis was adopted by thermal circuit concept which is suggested by Lee and Bender

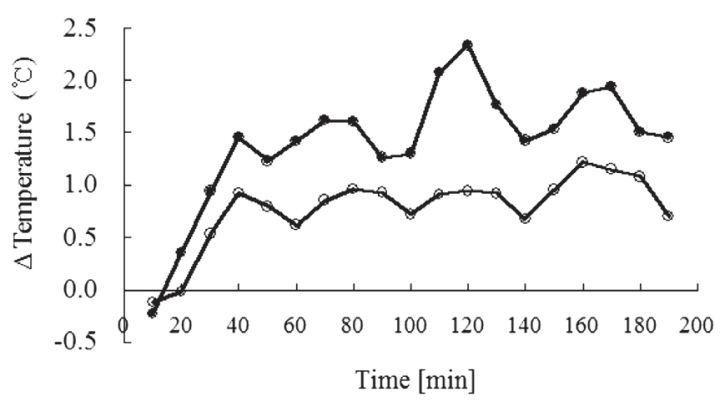

Fig. 2. Temperature difference between the inner and outer walls.

Note: open circles, low-density wood; filled circles, high-density fiberboard.

Table 3. Comparison of amounts of heat transferred

\begin{tabular}{|c|c|c|c|}
\hline \multirow{2}{*}{ Transfer mode } & \multirow{2}{*}{ Amount of heat transferred } & \multicolumn{2}{|c|}{ Comparison of heat transferred in box } \\
\hline & & Paulownia coreana & High-density fiberboard \\
\hline Conduction & $Q_{\text {cond }}=\Delta Q / \Delta t=k_{26.7 \mathrm{C}} \times A \times \Delta T / L$ & $0.13 \mathrm{~W}(0.69 \%)$ & $0.10 \mathrm{~W}(0.83 \%)$ \\
\hline Convection & $Q_{\text {conv }}=h_{\text {conv }} \times A_{\text {surf }} \times \Delta T$ & $4.5 \mathrm{~W}(25.0 \%)$ & $3.0 \mathrm{~W}(23.8 \%)$ \\
\hline Radiation & $Q_{\mathrm{rsdi}}=\sigma \times \varepsilon \times A_{\text {surf }}\left(T_{1}^{4}-T_{2}^{4}\right)$ & $13.4 \mathrm{~W}(74.3 \%)$ & $9.4 \mathrm{~W}(75.4 \%)$ \\
\hline Total & & $18.1 \mathrm{~W}(100 \%)$ & $12.5 \mathrm{~W}(100 \%)$ \\
\hline Efficiency & & $32.8 \%$ & $22.7 \%$ \\
\hline \multicolumn{2}{|c|}{ Total energy transferred to Vial and Water } & $4.48 \mathrm{~kJ}$ & $3.25 \mathrm{~kJ}$ \\
\hline
\end{tabular}

Note: Numbers in parentheses mean the percentage of transfer mode to total heat transferred. 
Table 4. Temperature change in water and vial

\begin{tabular}{ccccc}
\hline & $\begin{array}{c}\text { Temperature of water } \\
\text { (Initial, }{ }^{\circ} \mathrm{C} \text { ) }\end{array}$ & $\begin{array}{c}\text { Temperature of water } \\
\text { (After } 3 \text { hours, }{ }^{\circ} \mathrm{C} \text { ) }\end{array}$ & $\begin{array}{c}\text { Temperature of vial } \\
\text { (Initial, }{ }^{\circ} \mathrm{C} \text { ) }\end{array}$ & $\begin{array}{c}\text { Temperature of vial } \\
\text { (After } 3 \text { hours, }{ }^{\circ} \mathrm{C} \text { ) }\end{array}$ \\
\hline Paulownia coreana & 22.3 & 26.9 & 22.4 & 27.3 \\
HDF & 22.1 & 25.6 & 22.2 & 25.6 \\
\hline
\end{tabular}

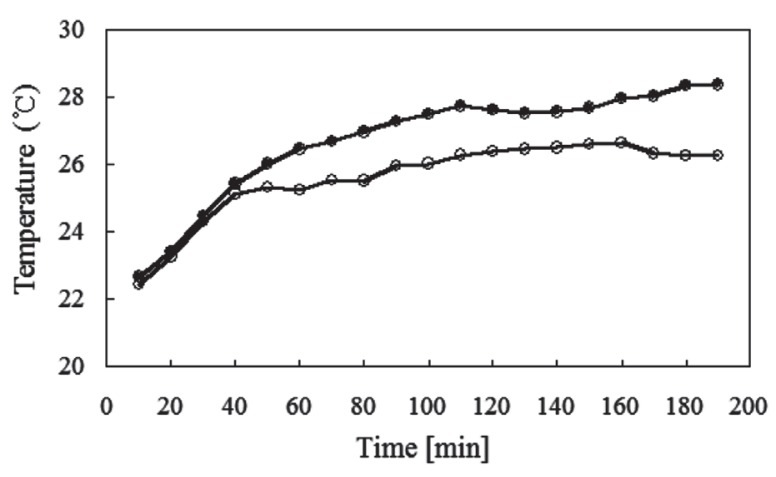

Fig. 3. Internal temperature at a height of $20 \mathrm{~cm}$

Note: open circles, high density fiberboard; filled circles, low density wood.

(2009). Table 3 shows a comparison of heat transfer. The heating panel provides $55 \mathrm{~W}$ of heat to each sample box; this transferred $18.1 \mathrm{~W}$ to the Paulownia coreana sample box and $12.5 \mathrm{~W}$ to HDF sample box. The largest portion of the heat transfer was a result of radiation (74$75 \%)$, followed by convection (23-25\%) and conduction (1\%). This clearly indicates that the heat transfer process is dominated by radiation.

\section{Total energy comparison of heating vial}

In this study, a vial of water was used to evaluate the heating effect that would be experienced by a human in the building. The vial was hung from the top of the box. The Paulownia coreana sample box yielded a higher temperature than HDF sample box both at spots on the surface of the vial and in the water, following 3 hours of heating (Table 4). A comparison of heat transfer $(Q)$ can be seen in Figure 3. The following formula was used to compare the consumption of energy, which resulted in an increase in the temperature of the vial and water,

$$
Q=m c \Delta T / Q=(m c \Delta T)_{\text {water }}+(m c \Delta T)_{\text {vial }},
$$

where $\mathrm{m}$ is the mass of the vial and water, $\mathrm{c}$ is the thermal capacity, and $\Delta \mathrm{T}$ is the temperature change of the vial and water. Energy can be checked though the following formulas to see the total energy difference according to material using

$$
\begin{aligned}
Q_{\text {Paulownia }} & =\left(0.2 \mathrm{~kg} \times 4.18 \mathrm{~kJ} / \mathrm{kg} \times 4.6^{\circ} \mathrm{C}\right)_{\text {water }} \\
& +\left(0.15 \mathrm{~kg} \times 0.84 \mathrm{~kJ} / \mathrm{kg} \times 4.9^{\circ} \mathrm{C}\right)_{\text {vial }}=4.48 \mathrm{~kJ},
\end{aligned}
$$

$$
\begin{aligned}
Q_{\mathrm{HDF}}= & \left(0.2 \mathrm{~kg} \times 4.18 \mathrm{~kJ} / \mathrm{kg} \times 3.4^{\circ} \mathrm{C}\right)_{\text {water }} \\
& +\left(0.15 \mathrm{~kg} \times 0.84 \mathrm{~kJ} / \mathrm{kg} \times 3.3^{\circ} \mathrm{C}\right)_{\text {vial }}=3.25 \mathrm{~kJ},
\end{aligned}
$$

$1.23 \mathrm{~kJ}$ of energy difference was found, leading to an increase in the temperature of both the vial and the water. The vial in the Paulownia coreana sample box received more energy than the vial in the HDF sample box. Based on these results, the relationship between heat and the vial can be considered to be parallel to the relationship of heat and a human. Therefore, the sample box with Paulownia coreana (a low-density wood) can be considered to transfer more heat to humans.

\section{Comparison of heat conduction according to mate- rial of wall and top section}

Heat transferred from the heating panel conducts to the internal air and top of the sample box. A temperature difference was observed between the bottom and top of the sample box, because there is significant heat in the internal air and little heat loss to the outside of the box. A temperature difference of $12.1^{\circ} \mathrm{C}$ was observed between the top and bottom sections, in addition to an average internal air temperature of $28.3^{\circ} \mathrm{C}$. The formula below was utilized to evaluate and calculate the amount of conducted heat transferred $\left(Q_{\text {cond }}\right)$ from bottom to top,

$$
Q_{\text {cond }}=\Delta Q / \Delta t=k_{26.7^{\circ} \mathrm{C}} \times A \times \Delta T / L,
$$

where $k_{26.7^{\circ} \mathrm{C}}$ is the heat conductivity of air at $26.7^{\circ} \mathrm{C}, A$ is the area of conduction, $\Delta T$ is the temperature difference between the top and bottom, and $L$ is the height between the top and bottom. $0.03 \mathrm{~W}$ of conduction difference was calculated, and

$$
\begin{aligned}
Q_{\text {Paulowia }} & =0.026 \mathrm{~W} /\left(\mathrm{m}^{\circ} \mathrm{C}\right) \times 0.16 \mathrm{~m}^{2} \\
& \times\left(40.7^{\circ} \mathrm{C}-28.6^{\circ} \mathrm{C}\right) / 0.4 \mathrm{~m}=0.13 \mathrm{~W} \\
Q_{\mathrm{HDF}}= & 0.026 \mathrm{~W} /\left(\mathrm{m}^{\circ} \mathrm{C}\right) \times 0.16 \mathrm{~m}^{2} \\
& \times\left(35.2^{\circ} \mathrm{C}-24.9^{\circ} \mathrm{C}\right) / 0.41 \mathrm{~m}=0.10 \mathrm{~W} .
\end{aligned}
$$

Few differences in heat conduction were observed based on material selection. In spite of specific gravity, there was a slight difference in conduction heat, from which it can be concluded that there is a small difference in conduction heat as a function of the specific gravity of the material (Kim, 2009: Seo and Kim, 2010).

We consider that this distinction is caused by the thermal conductivity of the material. The internal temperature of the sample box tends to increase when there is a slight heat loss to the outside of the specimen, with the exception of the bottom section; therefore, a lower thermal conductivity increases the internal temperature due to lower heat loss, as shown in Fig. 2. 
The thermal conductivities of the materials are 0.08 $\mathrm{W} / \mathrm{m} \cdot{ }^{\circ} \mathrm{C}$ (Paulownia coreana) and $0.10 \mathrm{~W} / \mathrm{m} \cdot{ }^{\circ} \mathrm{C}(\mathrm{HDF})$. Fig. 3 shows that the inner temperature of the Paulownia coreana box is higher than that of the HDF box as a result of lower thermal conductivity. Moreover, the inside and outside temperatures of the sample boxes can be used to determine the heat insulation properties of the materials. The sample box with Paulownia coreana was determined to have better heat insulation properties than those of the box made with HDF, based on the temperature distinction between the inside and outside of the box.

\section{Comparison of heat convection according to mate- rial}

The process of convection was due to heating of the internal air from the bottom to top, and the movement down of cool air from top to the bottom. The formula below shows the amount of heat transfer due to convection,

$$
Q_{\text {conv }}=h_{\text {conv }} \times A_{\text {surf }} \times \Delta T
$$

where $h_{\text {conv }}$ is the modulus of heat convection defined by $\frac{k}{L_{c}} \times N_{\mathrm{u}} \times A_{\text {surf }}, k$ is the thermal conductivity according to temperature, $L_{c}$ is the characteristic length, and $A_{\text {surf }}$ is the surface area. Values of $R_{\mathrm{a}}$ and $N_{\mathrm{u}}$ and can be calculated based on the formulas,

$$
\begin{aligned}
& R_{\mathrm{a}}=G_{\mathrm{a}} \times P_{\mathrm{r}}=\frac{g \times \beta\left(T_{\text {surf }}-T_{\text {envr }}\right) \times L_{\mathrm{c}}^{3}}{v^{2}} \times P_{\mathrm{r}} \text {, and } \\
& N_{\mathrm{u}}=0.27 R_{a}^{1 / 4},
\end{aligned}
$$

where $R_{\mathrm{a}}$ is the Rayleigh number, $\mathrm{Nu}$ is the Nusselt number, $g$ is the acceleration of gravity, $P_{\mathrm{r}}$ is the Prandtl number, $\beta$ is the coefficient of thermal expansion of the fluid, $T_{\text {surf }}$ is the temperature of a surface, and $T_{\text {env }}$ is the temperature of the environment. There was $1.5 \mathrm{~W}$ of heat convection based on the special gravity of the material, as shown here,

$$
\begin{aligned}
& R_{\text {a(Paulownia })}=\frac{9.81 \mathrm{~m} / \mathrm{s}^{2} \times 1 / 313.74(313.74-301.25) \times(0.4 / 4)^{3}}{\left(1.59 \times 10^{-5}\right)^{2}} \\
& \times 0.73=11.22 \times 10^{5}, \\
& N_{\mathrm{u}(\text { Paulownia })}=0.27 \times\left(11.22 \times 10^{5}\right)^{1 / 4}=8.79, \\
& h_{\text {conv(Paulownia) }}=2.26 \mathrm{~W} /\left(\mathrm{m}^{2 \circ} \mathrm{C}\right) \text {, } \\
& Q_{\text {conv(Paulownia) }}=2.26 \mathrm{~W} /\left(\mathrm{m}^{2 \circ} \mathrm{C}\right) \times 0.16 \\
& \times\left(40.7^{\circ} \mathrm{C}-28.3^{\circ} \mathrm{C}\right)=4.5 \mathrm{~W}, \\
& R_{\mathrm{a}(\mathrm{HDF})}=\frac{9.81 \mathrm{~m} / \mathrm{s}^{2} \times 1 / 308.24(308.24-299.34) \times(0.4 / 4)^{3}}{\left(1.57 \times 10^{-5}\right)^{2}} \\
& \times 0.73=8.34 \times 10^{5}, \\
& N_{\text {u(HDF })}=0.27 \times\left(8.34 \times 10^{5}\right)^{1 / 4}=8.16,
\end{aligned}
$$
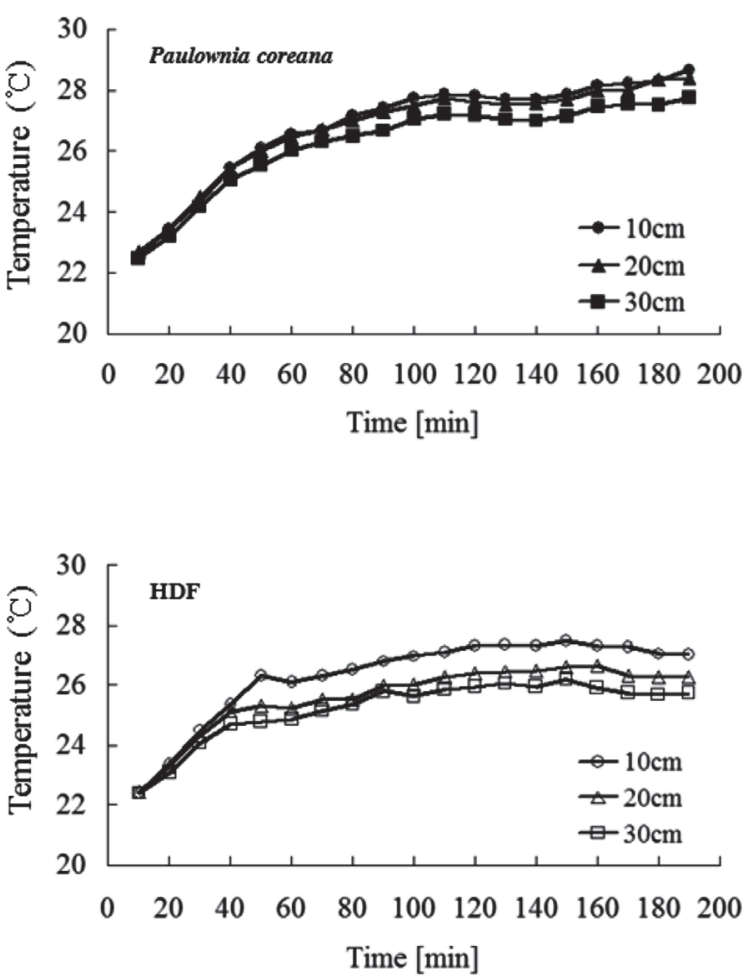

Fig. 4. Temperature difference based on height.

$$
\begin{aligned}
h_{\text {conv }(\mathrm{HDF})}= & 2.09 \mathrm{~W} /\left(\mathrm{m}^{2 \circ} \mathrm{C}\right), \\
Q_{\text {conv(HDF })}= & 2.09 / \mathrm{W} /\left(\mathrm{m}^{2 \circ} \mathrm{C}\right) \times 0.16 \\
& \times\left(35.2^{\circ} \mathrm{C}-26.3^{\circ} \mathrm{C}\right)=3.0 \mathrm{~W} .
\end{aligned}
$$

Heat convection shows the circulation of air inside the sample box. There was a $1.5 \mathrm{~W}$ distinction, according to the difference in specific gravity. In construction, wood with low specific gravity is typically considered to create more heat convection. Calculations also show that the heat circulated inside is greater than the heat to loss to the outside. As can be seen in Fig. 4, the convection of the sample box made with Paulownia coreana wood is more active than that of the HDF sample box, therefore, there is no difference in temperature. However, HDF has a 1 distinction when the temperature is rising, and is typically unstable because of the presence of two materials.

\section{Comparison of radiation heat as a function of mate-} rial

Radiated heat is energy transported in the form of light, and is present in all materials; therefore, the amount of radiated heat is greater than that of convection and conduction. The following formula,

$$
Q_{\text {rsdi }}=\sigma \times \varepsilon \times A_{\text {surf }}\left(T_{1}^{4}-T_{2}^{4}\right),
$$

is used for calculating the amount of thermal radiation (Cha JH et al., 2011), where $\sigma$ is the modulus of StefanBoltzman, $\varepsilon$ is the far-infrared radiation emissivity, $A_{\text {surf }}$ is the surface area, $T_{1}$ is the absolute temperature of the bottom, and $T_{2}$ is the average absolute temperature of 
the walls and top. There was a $4.0 \mathrm{~W}$ radiation difference according to specific gravity,

$$
\begin{aligned}
& Q_{\text {Paulownia }}=\left(5.67 \times 10^{-8}\right) \times 0.9 \times 0.16 \mathrm{~m}^{2} \times\left\{(273+40.7)^{4}\right. \\
&\left.-(273+26.5)^{4}\right\}=13.4 \mathrm{~W} \\
& Q_{\mathrm{HDF}}=\left(5.67 \times 10^{-8}\right) \times 0.85 \times 0.16 \mathrm{~m}^{2} \times\left\{(273+35.7)^{4}\right. \\
&\left.-(273+24.2)^{4}\right\}=9.4 \mathrm{~W} .
\end{aligned}
$$

The amount of heat transferred via radiation varied as a function of specific gravity. The amount of radiated heat is affected by the number of pores, which allow heated air to be trapped. Wood with low specific gravity radiated more heat than wood with high specific gravity, which may be a result of an increased number of pores absorbing more heated air.

\section{CONCLUSION}

In this study, two materials, Paulownia coreana and HDF, were used as the interior finishing material of sample boxes in order to determine the movement of heat and thermal efficiency. Results show that the low specific gravity wood (Paulownia coreana) is a more appropriate interior finishing material than high-density fiberboard because it shows a lower heat loss and a greater amount of heat transferred via radiation. The following represent the results of this study.

Based on $30 \mathrm{~W}$ of total heat, $18.1 \mathrm{~W}(60.3 \%)$ and $12.5 \mathrm{~W}(41.7 \%)$ were transferred to the inside of the Paulownia coreana and HDF boxes, respectively. It can be considered that the difference in heat loss is a function of the specific gravity of the wood.

The amount of heat transferred in the low specific gravity box was higher than that of the high specific gravity box. From this result, we recommend the use of low specific gravity wood as an interior finishing material in order to increase energy efficiency.

The amount of energy that a vial with water received was $4.48 \mathrm{~kJ}$ in the Paulownia coreana box, and $3.25 \mathrm{~kJ}$ in the HDF box. By assuming that the vial and water are the human body and blood, we have shown that people will feel warmer in a building finished in Paulownia coreana.

With wood, we found that most $(75 \%)$ of the heat is transferred via radiation. Heat transferred via radiation makes humans feel comfortably warmer, making wood an ideal material.

\section{ACKOWLEDGEMENTS}

This work was supported by a grant (S211313L010140) from the Forest Science \& Technology Projects, Forest Service. Republic of Korea.

\section{REFERENCES}

Cha JH, JK Seo and SM Kim 2011 Correlation Analysis of the Thermal Conductivity Heat Flow Meter and MTPS (Modified Transient Plane Source) Method Using Wood Flooring and Wall Material. J Korea Furniture Society 22(2): 118-1251

Kim SM 2009 Investigation on the mechanism of heat transfer in hot-pressing process of fiberboard manufacturing for laminate flooring. J Korea Furniture Society 20(5): 490-503

Kim YH, KS Lee, KH Nam, NC Park, SM Woo, MY Kim and HS Lim 2006 Economic analysis of electric heating appliances. The Korean Institute of Illuminating and Electrical Installation Engineers. 2006 Proceeding : 448-452

Korean Industrial Standard 2007 Flooring board, KS F 3103 Korean Agency for Technology and Standard, Seoul, pp. 1-15

Korean Industrial Standard 2010 Test methods for thermal transmission properties of thermal insulations, KS L 9016. Korean Agency for Technology and Standard, Seoul, pp. 1-13

Lee HH and D. A. Bender 2009 Far Infrared Emissivity of Wood Meterial - Comparing the Three Heat Transfer Modes of Wood Box and Aluminum Box. J Korean Wood Sci. and Technol. 37(5): 440-450

Maple Flooring Manufacturers Association 1967 Grading rules for hard maple; beech and birch flooring. http://www.maplefloor. org/literature/grading

Richardson B. A. 1976 Wood in construction. The construction Press Ltd, London, pp. 105-125

Seo JK and SM Kim 2010 A study on the improvement of thermal conductivity through heat conduction performance analysis of wood flooring. Proceedings of 2010 Symposium on Korean solar energy society: 49-54 